\title{
The Impact of Work Environment on the Average of Job Turnover in Five-Star Hotels in Al-Aqaba City
}

\author{
Mohammed A. Abu Rumman \\ Department of Business Administration \\ Al Balqa Applied University, Salt-Jordan \\ Tel: 692-77777-4819Ｅ-mail: abusharare_77@hotmail.com
}

\author{
Omar A. A. Jawabreh \\ Hotel and Tourism Management Department \\ Al Balqa Applied University, Aqaba, Jordan \\ E-mail: ojawabreh2000@yahoo.com
}

Khaled M. K. Alhyasat

Abu Dhabi University 'Visiting Assistant Prof. of HRM

E-mail: khaledheyasat@yahoo.com

Husam M. J. Abu Hamour

Department of Business Administration

AlBalqa Applied University, Jordan, AL-Salt

Received: July 17, 2013 Accepted: August 2, $2013 \quad$ Published: December 25, 2013

doi:10.5296/bms.v4i2.4020 URL: http://dx.doi.org/10.5296/bms.v4i2.4020 


\section{Abstract}

The purpose of this study is to identify the characteristics and elements of the work environment for the five-star hotels in the Al Aqaba city. It also aims to identify the average job turnover and its causes in five-star hotels in the Al Aqaba city.

The Findings indicate that there is a statistically significant impact of the work environment on the average job turnover in five-star hotels in Al Aqaba city. It also find that the average of salary considered the most influential factor on the average of job turnover followed by colleagues at work, safety system, health and safety system, taking into account humanitarian cases, the treatment of supervisor, continuous development through training, tools and equipment used by the department. Staffs' cafeteria, vacation \& leaves system, justice at work, health insurance system, housing allowance, shift work system, promotion system, pressure of work's hours, The reward system, the points system on salaries, finance incentives, and finally transportation allowance.

The study recommended that five-star hotels should concentrate on the special factors of working environment for its influential role on job turnover, through direct them towards the best, to reach to less turnover and thus to more stability, productivity and efficiently. It also recommended that administration should take into account the process of promotion for bachelors and married staffs.

Keywords: Work environment, Job turnover, Level of satisfaction 


\section{Introduction}

The hospitality manufacturing considers as one of the modern and advance business now. It is rapidly and expansion evolving business. The manufacturing of hospitality that contribute to creating jobs and new careers, hospitality activity covers important sectors contribute significantly to the national income, as a result of marketing and development of a variety of products and services to meet the changing needs of customers (Zgalat, 2003). The advantage of the hospitality manufacturing from the rest of the other sectors in that it seeks to achieve satisfaction of guests from a variety of services and intangible.

In 2002, there were 766 million international tourists. In 2006, expectations exceeded, figures indicate the World Tourism Organization that the number of tourists has reached 842 million international tourists, and there is hope that number will double by the year 2020. The Council of the World Travel and Tourism estimates that the travel industry as a responsible global economy both directly and indirectly $(11 \%)$ of the gross domestic product (GDP) at the global level, where it is hoped to be available (5.5) million new jobs until the year (2010). If the predictions are true, the new jobs will open up new opportunities for the hospitality and hotel sectors, entertainment, making conferences and exhibitions sector (Jordan Hotels Association, 2006).

Here comes the role of the working environment in maintaining human resources in the light of the high competition for the labour market hotel in Aqaba, through satisfy the needs and desires of employees in their work environment.

\section{Definition of Terms}

Working environment: is a framework represents what surrounds the individual in his field, and in his behavior towards his work, and affects his behavior, performance, and inclinations towards his work, the group that works with them, and administration that followed and the project to which he belongs. (Alshenwan, 1986: 205)

Internal work environment: is the general impression among the organization members, containing many variables such as the philosophy of senior management, working conditions, and the type of relations between the members of the organization. (Sulaiman, 1987: 27).

Organizational Structure: it is known as the formal organization of the roles and relationships between individuals in the organization and that directs the work towards achieving the goals and tasks, and sometimes referred to as to the scope or command authority (control unit) and is usually described as a formality in the organizational chart.

Turn over job: It can be defined as a "staff members leave their jobs voluntarily or by force" and is one of the big problems facing the hotels because leaving work costing hotel much money spent on recurring and training.

Job Turnover is a big problem in the hotel industry, ranging turnover ratio work in world-class hotels of $200 \%-300 \%$ annual, and for the managers about $100 \%$ due to the 
shortage of manpower specialized in Employment hotel and increase their demand, in addition to the Urban Renaissance in the construction of large hotels and witnessed during the last ten years, which led to increased demand for hotel employment.

\section{Problem of the Study}

The organizations concerned with the analysis and evaluation of all the internal factors, in order to state the strengths and weaknesses points that characterize each of the internal factors to take their strategic decisions, and selection of suitable alternatives to them. Overall, the analysis of the work environment is important and necessary step in choosing the right strategy of the organization to assess the capacity, human and material resources and moral available to them, which in turn works to determine the job turnover in the organizations.

Hence, the problem can be formulated the following questions.

1) Are five-star hotels in Al Aqaba providing a suitable working environment for its employees?

2) Is the work environment affects the average of employees turnover in five-star hotels in Al Aqaba?

\section{Objectives of the Study}

The present study aims to:

1) To identify the characteristics and elements of the work environment for the five-star hotels in the Al Aqaba city.

2) To identify the average job turnover and what are the causes in five-star hotels in the Al Aqaba city.

\section{Importance of the Study}

The importance of this study is to identify the impact of the work environment on the dropout average of staff for their work in five-star hotels. The importance of the study lies in following contributions, namely:

- The findings of the study contribute in identifying the capacity and potentiality of human and material resources available to the hotels.

- Identify the strengths points, to take its advantage and support it in the future in order to assist to eliminate obstacles to the work environment that affect the labour turnover in hotels.

- Identify weaknesses points, in order to overcome and avoided them by using some of the current strengths of the organization.

\section{Methodology of the Study}

Descriptive analytical approach is used to identify the impact of work environment on job 
turnover in five-star hotels in Al Aqaba city.

\subsection{The Population of the Study}

The population of the study consists of all five-star hotels in Aqaba.

\subsection{The Sample of the Study}

Random samples of employees were selected from five-star hotels in Al Aqaba city.

\subsection{Tool of the Study}

To achieve the objectives of the study, after reviewing the theoretical literature from sources and references, research and studies related to the impact of the work environment on job turnover in five-star hotels will use the questionnaire.

\subsection{Validity and Reliability of the Tool}

To verify the study tool (questionnaire), it has been presented to Dr. Qusay Qahtan, head of science of hotel and tourism at the College of Aqaba University. His recommendations and guidelines were taken into consideration, representing (80\%) of his opinions to judge the tool in terms of, add and delete items.

\subsection{Variables of the Study}

- Independent variable: the work environment.

- The dependent variable: Job turnover.

- Intermediary variable: the level of satisfaction, the salary system.

6.8 Model of the Study

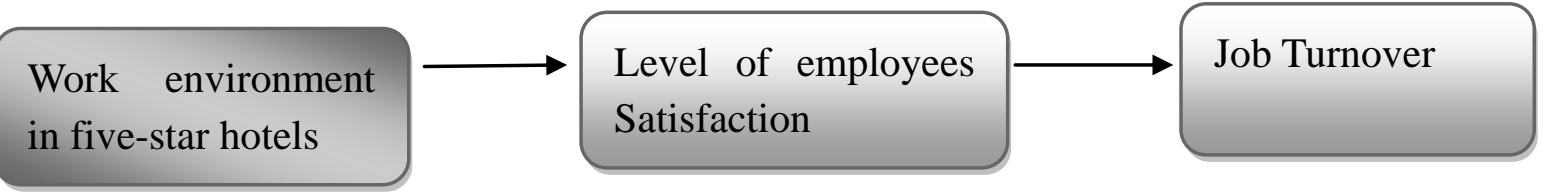

\subsection{Limitations of the Study}

1) Twenty questionnaires were excluded by one hotel because they did not response and get late for several days.

2) Another hotel did not accept the idea of distributing the questionnaires to the human resource department; therefore, we have distributed questionnaire to staff during their departures and arrivals to the hotel from outside the hotel.

3) The security staffs of another hotel have cooperated with us, but department of Human resource department refused to cooperate and asked us to come at another time after four or five days, and we have distributed questionnaire to staff during their departures and arrivals to the hotel from outside the hotel. 


\section{Hypotheses of the Study}

Based on the study aim and objectives, the following hypotheses can be formulated:

H1: There is a statistically significant effect of the work environment on the average job turnover in five-star hotels in Al Aqaba city.

$\mathrm{H} 2$ : There are differences in the impact of the work environment on job turnover based on gender variable.

H3: There are differences in the impact of the turnover on the work environment based on marital status variable.

H4: There are differences in the impact of the work environment on job turnover based on age variable.

H5: There are differences in the impact of the work environment on job turnover based on years of service in the tourism sector.

H6: There are differences in the impact of the work environment on job turnover based on the years of experience at hotel.

H7: There are differences in the impact of the work environment on job turnover based on the variable total salary.

\section{Literature Review}

Al Youbi (2000) investigated the impact of the moral side of the internal work environment in the civil public organizations on the level of performance. The sample of the study consists of (417) employees. The findings indicate that there is positive relationship between each of the supervisory method, participation, teamwork in the department or administrative unit, social services provided by the Department to the workers, mutual trust between the parties of the organization, enrich career and the level of performance of employees in the work environment within public organizations. The study recommended that there is need to build effective communicative system between the supervisor and his subordinates, support the social relations among them, as well as emphasizing the principle of participation, and the development of cooperation and coordination in the work among the working group in the administrative unit. The study also recommended paying attention to health and entertainment side of the staff, and consolidates the confidence they have in the organization in which they work, and enriching career.

AlBuqami, (2010) investigated the impact of the work environment in the work performance on the staff of the Department of passports in Makah. The study aims to identify the relationship between the dimensions of the work environment and the work performance of the staff of the Department of passports in Makah. The findings indicate that there is moderate correlation between the seven dimensions of the internal work environment and job performance. There are no statistically significant differences in personal variables towards 
the dimensions of the internal work environment. There are no statistically significant differences in personal variables towards the dimensions of job performance quality. The study recommended that more powers should be given to the staff commensurate with the size and responsibilities of each job. Paying attention to review the internal working procedures. The study also recommended that employee should participate in decision-making related to work, reconsider the current rewards system and Increase the use of modern technical means, which help in the completion of the work accuracy and fast.

Raslan (1978) conducted a study entitled "work environment and worker productivity between thought and the reality of management in Egypt". The study indicates that comforts of workers have good reaction in the motivation to work. This study was based on the following factors: (weather, lighting, noise, health conditions in the workplace, hygiene, ventilation). After studying these factors, the study recommended that the following should be available: Lighting, proper ventilation, Avoid noise, Provide good lighting in the streets and buildings.

Al-Majali (1999) conducted a study entitled "The Impact of social work environment on job satisfaction of a sample of workers in the factories of Arab Potash Company in the Karak governorate". The study aimed to shed light on the work environment and their relative importance to influence job satisfaction using the entrance of human relations. The findings indicate that there is a sense of satisfaction regard work. Social factors (such as friendship, belonging to non-official working groups, a sense of security and career stability) are more important than some physical factors (such as wages, financial incentives, the physical conditions of the work).

Athamneh (2004) conducted a study aiming to assess the degree of job satisfaction among faculty members in the central Jordanian universities, also aimed to detect the impact of factors (gender, marital status, academic rank, college, and experience). The researcher has developed a tool of the study, which included five areas of job satisfaction (objectives and policies of higher education, laws, regulations and instructions, leadership and decision-making, academic freedom of faculty members, and organizational climate).

Albaker (2008) conducted a study entitled "Analysis of the impact of organizational and personal factors to consider oneself in the work environment". The findings indicates that the following factors are the most influential in the concept of self as a (independence at work, career advancement, social and economic level, length of service).

Shlol (1999) conducted a study to identify the level of job satisfaction among administrative leaders in governmental and private Jordanian universities, and the factors influencing them from their point of view. The researcher tries to answer the following questions: What is the level of job satisfaction among administrative leaders in the government and private Jordanian universities based on the six job satisfaction factors contained in the measurement of job satisfaction, and the overall level of job satisfaction? Are there any statistically significant differences between the arithmetical averages of the answers of administrative 
leaders? How to arrange the influencing factors on job satisfaction? Is it according to their importance from the standpoint of administrative leaders in Jordanian universities? The study tool consists of three parts: the first relates to information of the respondent, the second is a measure of job satisfaction, and the third is the order of job satisfaction factors according to their importance. Albashareh (2005) also, conducted a study to investigate the impact of organizational environment on job satisfaction among administrative staff at Al al-Bayt University and the University of Jerash.

Guilding \& Timo, (2006) investigated the hiring practices in the five and four stars hotels domestic and international operating in the Gold Coast in Australia. The study conducted qualitative and quantitative research to obtain the required data. The findings showed the weakness of the structures responsible for human resources in the hotels surveyed, despite the obvious growth in the educational levels of workers in Australia and increase the activity of training hotel. The bad things in this sector are the (lack of skill, seasonal work, little compensation, bad working conditions, frequent mobility at work, poor management).The study also showed that there is a relationship between compensation and job turnover. The study also exposed to the advantages obtained by workers in the hospitality sector.

Lynn (2002) conducted a study to address the relationship of turnover work with sales as one of the performance indicators in this sector as well as the relationship of turnover work with service and tips. The sample was selected randomly consists of (500) managers. The study found that the most important problems facing workers in hotels and affects job satisfaction is the paucity of opportunities for promotion, a low level of income, and the differences among employees.

By reviewing the previous studies, the researchers note that the instability of the relationship between job satisfaction and personal, institutional and functional characteristics from one study to another, multiple dimensions and aspects of job satisfaction inherent in the working conditions, institutional and content. Few studies of job satisfaction and scarcity in the area of employees in hotels at various levels functional. However, in all studies conducted in this area there is a number of key elements related to the job satisfaction which contains: Income source, promotion opportunities, work environment, the positive relationship between management and workers, the relationship between the workers themselves, the attention of management to the job and labour. In addition, the degree of staff satisfaction and happiness to their work, the presence of industrial security, the sense of pride in their work and workers promote team spirit, and the interrelationship between management and employees.

Because of the scarcity of studies on job satisfaction for workers in the hotel industry. The researchers decided to conduct research and study to identify the aspects relating to the consent of the Jordanian workers in the hotels in an attempt to provide the necessary information in this regard. According to the researchers best knowledge this study considers the first study in Jordan measuring the factors affecting and causing turnover of work in five-star hotels in Al-Aqaba city. 


\section{Analysis of the Study}

Statistical analysis used to test hypotheses using statistical and mathematical methods and techniques, to know the accepted and non-accepted hypotheses.

\subsection{The Stability of the Tool}

Cronbach's $\alpha$ (alpha) as a coefficient of reliability was used to measure the internal consistency for all variables. Table (1) shows the following: the value of alpha is 0.82 that means it is higher than 0.60 , which indicate the stability in the instrument of the study.

Table (1). Cronbach's Alpha test results

\begin{tabular}{|l|l|l|}
\hline Scope & No. Items & Value of Alpha \\
\hline Total & 20 & 0.82 \\
\hline
\end{tabular}

9.2 Description of Demographics and Personal Factors of the Respondents

Table 2. below shows that:

- Gender: $80.5 \%$ of the samples are male, and the rest are female.

- Age: $40.2 \%$ of the samples' age range between 20-25 years, and $23.0 \%$ of the samples' age range between $29-34$ years. $16.1 \%$ of the samples' age is 35 plus.

- Marital Status: $52.9 \%$ of the samples are married, and $47.1 \%$ are bachelors.

\section{Years of service in the tourism sector:}

$35.6 \%$ of the sample experiences ranging between 1-2 years, $33.3 \%$ of the sample experiences ranging between 3-5 years, $21.8 \%$ their experiences range between 6-10 years, and $9.2 \%$ of the samples have 11 years experience or more.

Years of experience in the hotel: $33.3 \%$ of the sample experiences are less than 2 years, 16.1 $\%$ their experiences range between 4-5 years and the same percentage of the same have more than 6 years experience.

\section{Total salary:}

$48.3 \%$ of respondents' salaries range from 200-350, 36.8\% of respondents' salaries range from 351-500 JD, $8.0 \%$ of respondents' salaries range from 501-650 JD, and 6.9\%, ranging from 651JD or above.

Table (2). shows frequencies and percentages for personal and functional variables of respondents

\begin{tabular}{|l|c|c|c|}
\hline Variables & Category & Frequency & Percentage \% \\
\hline Gender & Male & 70 & 80.5 \\
\hline & Female & 17 & 19.5 \\
\hline
\end{tabular}




\begin{tabular}{|c|c|c|c|}
\hline \multirow[t]{2}{*}{ Marital Status } & Bachelor & 41 & 47.1 \\
\hline & Married & 46 & 52.9 \\
\hline \multirow[t]{4}{*}{ Age } & $25-20$ & 35 & 40.2 \\
\hline & $29-26$ & 18 & 20.7 \\
\hline & $34-30$ & 20 & 23.0 \\
\hline & 35-above & 14 & 16.1 \\
\hline \multirow{4}{*}{$\begin{array}{l}\text { Years of } \\
\text { experience in } \\
\text { tourism sector }\end{array}$} & $2-1$ & 31 & 35.6 \\
\hline & $5-3$ & 29 & 33.3 \\
\hline & $10-6$ & 19 & 21.8 \\
\hline & 11- above & 8 & 9.2 \\
\hline \multirow{4}{*}{$\begin{array}{l}\text { Years of } \\
\text { experience in the } \\
\text { current hotel }\end{array}$} & Less than 2 & 28 & 32.2 \\
\hline & $3-2$ & 31 & 35.6 \\
\hline & $5-4$ & 14 & 16.1 \\
\hline & 6- above & 14 & 16.1 \\
\hline \multirow[t]{4}{*}{ Total salary } & $350-200$ & 42 & 48.3 \\
\hline & $500-351$ & 32 & 36.8 \\
\hline & $650-501$ & 7 & 8.0 \\
\hline & 651-above & 6 & 6.9 \\
\hline
\end{tabular}

\subsection{Testing Hypotheses}

\section{First Hypothesis}

H1: There is a statistically significant effect of the work environment on the average job turnover in five-star hotels in Al Aqaba city.

Table (3) below shows that all the statements got means greater than 3.00, and the level of significance is less than 0.05 , therefore, the first hypothesis is accepted and there is a statistically significant effect of the work environment on the average job turnover in five-star hotels in Al Aqaba city. 
Table (3). Mean, standard deviation, $t$ value and level of significance regard the impact of the work environment on the average job turnover

\begin{tabular}{|c|l|c|c|c|c|c|}
\hline No. & Items & Mean & $\begin{array}{c}\text { Standard } \\
\text { Deviation }\end{array}$ & t-Value & $\begin{array}{l}\text { Level of } \\
\text { Sig }\end{array}$ & Level \\
\hline 1 & Salary average & 4.21 & 0.86 & 13.02 & 0.00 & 1 \\
\hline 2 & Promotion System & 3.71 & 0.98 & 6.82 & 0.00 & 15 \\
\hline 3 & Treatment of supervisor & 3.92 & 0.93 & 9.22 & 0.00 & 6 \\
\hline 4 & Colleagues at work & 4.05 & 0.98 & 10.00 & 0.00 & 2 \\
\hline 5 & The reward system & 3.64 & 1.09 & 5.51 & 0.00 & 17 \\
\hline 6 & Leaves \& Vacations System & 3.85 & 0.97 & 8.17 & 0.00 & 10 \\
\hline 7 & pressure of work hours & 3.67 & 1.02 & 6.10 & 0.00 & 16 \\
\hline 8 & Occupational Safety System & 4.00 & 0.99 & 9.44 & 0.00 & 3 \\
\hline 9 & Points on the payroll system & 3.57 & 1.13 & 4.76 & 0.00 & 18 \\
\hline 10 & Tools and equipment used in the & 3.86 & 1.12 & 7.16 & 0.00 & 8 \\
& section & & & & & \\
\hline 11 & staff s' Cafeteria & 3.86 & 1.07 & 7.52 & 0.00 & 9 \\
\hline 12 & System of work shifts & 3.77 & 1.00 & 7.21 & 0.00 & 14 \\
\hline 13 & Housing allowance & 3.78 & 1.25 & 5.82 & 0.00 & 13 \\
\hline 14 & Health insurance system & 3.79 & 1.01 & 7.30 & 0.00 & 12 \\
\hline 15 & Transportation allowance & 3.36 & 1.41 & 2.35 & 0.02 & 20 \\
\hline 16 & Health and safety system & 3.99 & 0.95 & 9.75 & 0.00 & 4 \\
\hline 17 & Finance incentives & 3.52 & 1.10 & 4.39 & 0.00 & 19 \\
\hline 18 & Continuous development through & 3.92 & 0.87 & 9.91 & 0.00 & 7 \\
\hline 19 & Taking into account humanitarian & 3.94 & 1.03 & 8.56 & 0.00 & 5 \\
\hline 20 & Justice at work & 3.80 & 1.18 & 6.36 & 0.00 & 11 \\
\hline & Total & 3.81 & 0.66 & 11.49 & 0.00 & \\
\hline
\end{tabular}

All the above statements got means greater than 3.00, and the level of significance is less than 0.05 , therefore all of these variables affect the turnover of the work.

The statement No. 1, got highest mean 4.21 i.e. the average of salary is the most influential of job turnover.Followed by statement No. 4 relating to colleagues at work, then statements No. 8, 16, 19, 3.18, 10, 11, 6, 20, 14, 13, 12, 2, 7, 5, 9, 17. Statement No.15 related to transportation allowance ranked last with a mean 3.36, where it is less impact on job turnover.

Second Hypothesis:

$\mathrm{H} 2$ : There are differences in the impact of the work environment on job turnover based on gender variable. 


\section{MInstitute Machink $_{\text {Int }}$}

Table (4) below shows that there are three statistical differences, first is salary average hence, the level of significance is less than 0.05, the differences was in favour of females, therefore, salary average affects female job turnover more than its impact on male job turnover. The second difference relates to the transportation allowance is also in favour of females, as it affects female job turnover more than its impact on male job turnover.

The third difference is in the area of continuous development through training is also in favour of females, it affects female job turnover more than its impact on male job turnover. The rest of above statements are not significant, hence the level of significance is greater than 0.05 , the above rest statements got level of significance 0.58 ; therefore, this hypothesis is rejected. Therefore, there are no differences in the impact of the work environment on job turnover based on gender variable.

Table (4). Results of the test based on gender variable

\begin{tabular}{|l|l|l|l|l|}
\hline No & Statement & \multicolumn{2}{l|}{ Mean } & Level of Sig \\
\hline \multicolumn{2}{|l|}{} & Female & Male & \\
\hline 1 & Salary average & 4.29 & 3.67 & 0.02 \\
\hline 2 & Promotion System & 4.00 & 3.64 & 0.17 \\
\hline 3 & Treatment of supervisor & 3.88 & 3.93 & 0.85 \\
\hline 4 & Colleagues at work & 3.82 & 4.10 & 0.29 \\
\hline 5 & The reward system & 3.82 & 3.60 & 0.45 \\
\hline 6 & Leaves \& Vacations System & 4.00 & 3.81 & 0.48 \\
\hline 7 & pressure of work hours & 3.24 & 3.77 & 0.06 \\
\hline 8 & Occupational Safety System & 3.82 & 4.04 & 0.41 \\
\hline 9 & Points on the payroll system & 3.12 & 3.69 & 0.07 \\
\hline 10 & Tools and equipment used in the section & 4.18 & 3.79 & 0.20 \\
\hline 11 & staff s' Cafeteria & 3.82 & 3.87 & 0.87 \\
\hline 12 & System of work shifts & 3.59 & 3.81 & 0.40 \\
\hline 13 & Housing allowance & 4.12 & 3.70 & 0.21 \\
\hline 14 & Health insurance system & 4.41 & 4.16 & 0.28 \\
\hline 15 & Transportation allowance & 4.06 & 3.19 & 0.03 \\
\hline 16 & Health and safety system & 4.35 & 3.90 & 0.08 \\
\hline 17 & Finance incentives & 3.71 & 3.47 & 0.43 \\
\hline 18 & Continuous development through training & 4.29 & 3.83 & 0.04 \\
\hline 19 & Taking into account humanitarian cases & 3.82 & 3.97 & 0.59 \\
\hline 20 & Justice at work & 3.47 & 3.89 & 0.19 \\
\hline & Total & 3.89 & 3.79 & 0.58 \\
\hline
\end{tabular}

Third Hypothesis:

H3: There are differences in the impact of the turnover on the work environment based on marital status variable. 


\section{Macrothink}

Table (5) below shows that there are three statistical differences regard to promotion system, hence, the level of significance is 0.02 , the level of significance is less than 0.05 and it was in favour of bachelors, therefore, promotion system has its impact on bachelors job turnover more than married job turnover.

The rest of statements are not significant, hence, the level of significance is greater than 0.05 , and all the rest statements got level of significance 0.52 ; therefore, this hypothesis is rejected. Therefore, there are no differences in the impact of the turnover on the work environment based on marital status variable.

Table (4). Results of the test based on marital status variable

\begin{tabular}{|c|c|c|c|c|}
\hline No & Statement & Mean & & Level of \\
\hline & & Bachelor & Married & \\
\hline 1 & Salary average & 3.83 & 3.76 & 0.75 \\
\hline 2 & Promotion System & 3.98 & 3.48 & 0.02 \\
\hline 3 & Treatment of supervisor & 4.10 & 3.76 & 0.09 \\
\hline 4 & Colleagues at work & 4.24 & 3.87 & 0.07 \\
\hline 5 & The reward system & 3.71 & 3.59 & 0.61 \\
\hline 6 & Leaves \& Vacations System & 4.07 & 3.65 & 0.04 \\
\hline 7 & pressure of work hours & 3.51 & 3.80 & 0.18 \\
\hline 8 & Occupational Safety System & 3.95 & 4.04 & 0.66 \\
\hline 9 & Points on the payroll system & 3.49 & 3.65 & 0.50 \\
\hline 10 & Tools and equipment used in the section & 3.88 & 3.85 & 0.90 \\
\hline 11 & staff s' Cafeteria & 3.95 & 3.78 & 0.46 \\
\hline 12 & System of work shifts & 3.61 & 3.91 & 0.15 \\
\hline 13 & Housing allowance & 3.59 & 3.96 & 0.17 \\
\hline 14 & Health insurance system & 4.05 & 4.35 & 0.10 \\
\hline 15 & Transportation allowance & 3.44 & 3.76 & 0.60 \\
\hline 16 & Health and safety system & 4.05 & 3.48 & 0.57 \\
\hline 17 & Finance incentives & 3.66 & 3.76 & 0.26 \\
\hline 18 & Continuous development through training & 4.12 & 3.87 & 0.03 \\
\hline 19 & Taking into account humanitarian cases & 4.10 & 3.59 & 0.18 \\
\hline 20 & Justice at work & 3.85 & 3.65 & 0.71 \\
\hline & Total & 3.86 & 3.80 & 0.52 \\
\hline
\end{tabular}

Fourth Hypothesis:

H4: There are differences in the impact of the work environment on job turnover based on age variable.

Table (6) below shows that there are no statistical differences based on age variable, hence, all the statements got level of significance greater than 0.05 , except statement No. 2 . 


\section{Macrothink}

Therefore, there are no statistical differences based on age variable.

Statement No.2 got level of significance is less than 0.05 , therefore, there is statistical differences in the impact of promotion system on age variable.

The level of significance for the all of the statement is 0.42 , therefore, this hypothesis is rejected. Therefore, there are no differences in the impact of the turnover on the work environment based on age variable.

\section{Fifth Hypothesis:}

H5: There are differences in the impact of the work environment on job turnover based on years of service in the tourism sector.

Table (6) below shows that there are no statistical differences based on years of service in the tourism sector variable, hence, all the statements got level of significance greater than 0.05 , except statement No. $16 \& 18$. Therefore, there are no statistical differences based on years of service in the tourism sector variable.

Statement No.16 got level of significance is less than 0.05 , therefore, there is statistical differences in the impact of Health and safety system on years of service in the tourism sector variable.

Statement No.18 got level of significance is less than 0.05, therefore, there is statistical differences in the impact of continuous training on years of service in the tourism sector variable.

The level of significance for the all of the statement is 0.18 , so, this hypothesis is rejected. Therefore, there are no differences in the impact of the turnover on the work environment based on years of service in the tourism sector variable.

Table (6). Results of the test based on age, years of service in the tourism sector and in the current hotel, variables

\begin{tabular}{|l|l|l|l|l|l|}
\hline No. & Items & $\begin{array}{l}\text { F value } \\
\text { Age } \\
\text { Variable }\end{array}$ & $\begin{array}{l}\text { F value } \\
\text { tourism } \\
\text { sector } \\
\text { services }\end{array}$ & $\begin{array}{l}\text { F value } \\
\text { current } \\
\text { hotel } \\
\text { experience }\end{array}$ & $\begin{array}{l}\text { F value } \\
\text { total } \\
\text { salary }\end{array}$ \\
\hline 1 & Salary average & 0.19 & 0.20 & 0.30 & 0.04 \\
\hline 2 & Promotion System & 0.00 & 0.12 & 0.94 & 0.37 \\
\hline 3 & Treatment of supervisor & 0.18 & 0.31 & 0.12 & 0.33 \\
\hline 4 & Colleagues at work & 0.78 & 0.80 & 0.31 & 0.62 \\
\hline 5 & The reward system & 0.13 & 0.93 & 0.35 & 0.73 \\
\hline 6 & Leaves \& Vacations System & 0.94 & 0.07 & 0.28 & 0.39 \\
\hline 7 & pressure of work hours & 0.04 & 0.13 & 0.84 & 0.39 \\
\hline 8 & Occupational Safety System & 0.48 & 0.87 & 0.63 & 0.16 \\
\hline
\end{tabular}




\begin{tabular}{|l|l|l|l|l|l|}
\hline 9 & Points on the payroll system & 0.71 & 0.13 & 0.29 & 0.87 \\
\hline 10 & $\begin{array}{l}\text { Tools and equipment used in the } \\
\text { section }\end{array}$ & 0.36 & 0.54 & 0.16 & 0.09 \\
\hline 11 & staff s' Cafeteria & 0.22 & 0.27 & 0.15 & 0.99 \\
\hline 12 & System of work shifts & 0.27 & 0.50 & 0.76 & 0.12 \\
\hline 13 & Housing allowance & 0.88 & 0.70 & 0.19 & 0.06 \\
\hline 14 & Health insurance system & 0.17 & 0.15 & 0.07 & 0.01 \\
\hline 15 & Transportation allowance & 0.70 & 0.10 & 0.15 & 0.29 \\
\hline 16 & Health and safety system & 0.34 & 0.02 & 0.59 & 0.07 \\
\hline 17 & Finance incentives & 0.40 & 0.08 & 0.29 & 0.54 \\
\hline 18 & $\begin{array}{l}\text { Continuous development through } \\
\text { training }\end{array}$ & 0.29 & 0.00 & 0.64 & 0.36 \\
\hline 19 & $\begin{array}{l}\text { Taking into account humanitarian } \\
\text { cases }\end{array}$ & 0.55 & 0.55 & 0.59 & 0.07 \\
\hline 20 & Justice at work & 0.45 & 0.14 & 0.37 & 0.03 \\
\hline & Total & 0.41 & 0.18 & 0.49 & 0.54 \\
\hline
\end{tabular}

Sixth Hypothesis:

H6: There are differences in the impact of the work environment on job turnover based on the years of experience at current hotel.

Table (6) above shows that all the statements got level of significance greater than 0.05 , Therefore, there are no statistical differences based on the years of experience at the current hotel variable.

The level of significance for the all of the statement is 0.49 , so, this hypothesis is rejected. Therefore, there are no differences in the impact of the turnover on the work environment based on years of experience at the current hotel variable.

\section{Seventh Hypothesis:}

H7: There are differences in the impact of the work environment on job turnover based on the variable total salary.

Table (6) above shows that all the statements got level of significance greater than 0.05 , except statement No. $1,14 \& 20$. Therefore, there are no statistical differences based total salary variable.

Statement No.1 got level of significance less than 0.05, therefore, there are statistical differences in the impact of salary average on total salary variable.

Statement No.14 got level of significance less than 0.05, therefore, there is statistical differences in the impact of health insurance system on total salary variable.

Statement No.20 got level of significance less than 0.05 , therefore, there is statistical 
differences in the impact of Justice at work on total salary variable.

The level of significance for the all of the statement is 0.54 , so, this hypothesis is rejected. Therefore, there are no differences in the impact of the turnover on the work environment based on total salary variable.

\section{Findings \& Recommendations}

\subsection{Finding: The Study Found the Following Results}

- There is a statistically significant impact of the work environment on the average job turnover in five-star hotels in $\mathrm{Al}$ Aqaba city.

- The average of salary considered the most influential factor on the average of job turnover followed by colleagues at work, safety system, health and safety system, taking into account humanitarian cases, the treatment of supervisor, continuous development through training, tools and equipment used by the department. Staffs' cafeteria, vacation $\&$ leaves system, justice at work, health insurance system, housing allowance, shift work system, promotion system, pressure of work's hours, The reward system, the points system on salaries, finance incentives, and finally transportation allowance.

- The percentage of males in the hotel business is more than females.

- The promotion system affects the turnover of work when staff at the hotel using cronyism and nepotism.

- The factor of development through training affects the turnover of work of bachelor's staff more than married. Therefore, job turnover of bachelors is more than married staffs.

- The factor colleagues at work affect the average job turnover of bachelor's staff more than married.

- The most of the staff in five-star hotels are of the youth category.

\subsection{Recommendations}

The present study recommended the following:

- The study recommended that five-star hotels concentrate on the special factors of working environment for its influential role on job turnover, through direct them towards better, to reach to less turnover and thus to more stability, productivity and efficiently.

- The study also focused on financial incentives such as salary average because it is the most influential job turnover. As well as promoting good relations among staff \& colleagues.

- The study recommended that administration make women's work most of the times in the morning.

- The study recommended that administration take into account the process of promotion 
for bachelors and married staffs. Because administration believes that bachelors do not have great loyalty great for staying in his work, because they have no responsibilities outside of work, such as married staffs who have great responsibilities outside of work, such as family responsibility that makes them stay in their work.

- The study recommended that administration should take care of youth staff and reward them financially and morally because they are more at the hotel.

- The study recommended that administration should take into account the development process through the training of bachelors and married staffs.

- The study recommended that administration should strengthen the relationship between the staff and provide social climate of work among employees; because the bachelors' staff do not have external relations in order to finds psychological comfort and stability with other employees at the facility.

- The study recommended conducting further studies to investigate the role of the working environment on other variables such as the efficiency and effectiveness of the staff.

\section{References}

Al-Bakr, M. (2008). Analysis of the impact of organizational and personal factors in considering oneself in the work environment.

Al-Bashareh, A. (2005). The impact of organizational climate on job satisfaction among administrative staff at Al al-Bayt University and Jerash private University. Unpublished Master thesis, Al al-Bayt University, Jordan.

Al-Buqami, M. (2010). The impact of the work environment in the job performance a case study of staff of the Department of passports in Makah. Master thesis.

Al-Majali, F. (1999). Social Impact of work environment on job satisfaction of a sample of employees in Arab Potash factories in Al Karak.

Al-Shamari, I. (2002). The impact of human resource management strategies in promoting TQM, Master Thesis, University of Baghdad, Baghdad, Iraq.

Al-Shlool, A. (1999). Job satisfaction among administrative leaders in governmental and private Jordanian universities, and the factors influencing it from their point of view, unpublished Ph.D. thesis, University of Khartoum, Sudan.

Al-Youbi, A. (2000). The moral dimension of the internal work environment and its impact on the level of performance: An Empirical Study for the public organizations in Jeddah, Master thesis.

Al-Zgalat, Z. (2003). The effect of the compensation system at the level of performance of employees in the Jordanian commercial banks, Master thesis, Al al-Bayt University, Jordan. Association of Jordan Hotels, Annual Report for the year 2006. 
Athamne, N. (2004). Estimate the degree of job satisfaction as perceived by faculty members in the official Jordanian Universities PhD thesis, Yarmouk University, Jordan.

Guilding, \& Timo. (2006). Employment.Flexibility and Market practices of Domestic and MNCChain Luxury Hotels in Australia.

Jameeli, Q. (2010). Human resources management in the tourism and hotel facilities. Yaghi publication, Jordan.

Lynn. (2002). Turnovers Relationships with Sales. Tips and Service across Restaurants in a Chain'.

Maher, A. (1999). Step-by-step guide for managers in Strategic Management. University Publication, Alexandria.

Ruslan, N. (1978). Work environment and employee productivity between thought and the reality of administrative in Egypt.

The government of Jordan. (2004). The Ministry of Tourism and Antiquities, the Jordan National Tourism Strategy for the period (2004-2010).

The Jordanian government. (2001). The Ministry of Tourism and Antiquities, Conditions of the hotels. 